\title{
Rancang Bangun Kendali Perangkat Elektronik Dan Monitoring Daya Listrik Berbasis Bluetooth
}

\author{
Kuni Nadliroh ${ }^{1)}$, Elsanda Merita Indrawati ${ }^{2)}$ \\ 1)Teknik Mesin, Universitas Nusantara PGRI Kediri \\ ${ }^{2}$ Teknik Elektronika, Universitas Nusantara PGRI Kediri \\ E-mail: ${ }^{1}$ kuninadliroh@ unpkediri.ac.id , ${ }^{2)}$ elsanda07@ gmail.com
}

\begin{abstract}
Abstrak
Daya merupakan salah satu satuan dalam listrik yang kita pakai dalam kehidupan sehari-hari. Penggunaan pengontrol daya memudahakan controller untuk mengendalikan daya yang terdapat dalam suatu piranti elektronika. Pengontrol daya dalam penelitian ini merupakan pengontrolan daya semu yang menggunakan bluetooth dan android yang mana alat ini didesain secara sederhana dan mudah digunakan sehingga meningkatkan daya kefleksibilitasan alat. penggunaan media bluetooth dan android mempermudah pengontrolan daya semu jarak jauh sehingga dalam suatu ruangan atau beberapa alat yang terdapat dalam satu ruangan lebih mudah dalam melakukan pengontrolan daya semu. Tujuan dari penelitian ini adalah terciptanya alat pengontrol daya semu yang dapat digunakan dalam kehidupan sehari-hari baik dalam bidang industri maupun dalam rumah tangga yang mudah dan murah.
\end{abstract}

Kata Kunci: Bluetooth, Daya, Android

\begin{abstract}
Power is one unit in electricity that we use in everyday life. The use of a power controller makes it easy for the controller to control the power contained in an electronic device. The power controller in this study is a pseudo power control that uses Bluetooth and Android, which is designed to be simple and easy to use, thus increasing the flexibility of the device. the use of bluetooth and android media makes it easier to control the apparent power remotely so that in a room or several devices contained in one room it is easier to control pseudo power. The purpose of this research is the creation of pseudo power control devices that can be used in everyday life both in the field of industry and in households that are easy and inexpensive.
\end{abstract}

Keywords:Bluetooth, Power, Android

\section{PENDAHULUAN}

Perkembangan teknologi sangat pesat, hal ini memberikan dampak yang positif dan negaif, dampak negatifnya masyarakat cenderung konsumtif dan menjadi pealas akan tetapi dampak positifya adalah pekerjaan manusia menjadi cepat selesai. Seiring dengan kemajuan alat digital juga meningkatkan kemampuan alat ukur, kemajuan teknologi digital ini menyebabkan peneliti dalam bidang listrik dan 
elekronika untuk melakukan peneltian yang lebih baik lagi mengeni sistem kendali dan moitoring penggunaa daya, dimana daya merupakan faktor utama dala suatu komponen.

Era yang semakin canggih dan konsumsi listrik untuk memenuhi kebutuhan sehari hari meingkat, bahkan mansia tdak bisa lepas dari keberadaan listrik. Pasokan listrik yang terus menerus setiap hari meningkatkan usaha PT PLN untuk menghasilkan lisrik semakin besar, sedangkan untuk menghasilkan energi lisrik yang besar tersebut juga membutuhkan biaya yang banyak. Tanpa adanya sistem kotrol daya listrik yang digunakan maka perangkat elektronik tersebut akan mengalami pemborosan daya listrik.

Dalam kehidupan sehari-hari perangkat elektronika memiliki kemampuan komputasi yang berkembang, mulai penggunaan remote control yang memanfaatkan IR, akan tetapi juga ada lampu yang masih menggunakan sistem manual, tentunya hal ini disesuaikan dengan kebutuhan. Terdapat sah satu teknologi baru yang memanfaatkan gelombang radio yaitu bluetooth. Penggunaa bluetooth sendiri lebih menguntungkan pengguna yaitu pengguna bisa melakukan kontroling terhadap alat yang digunakan dengan jarak yang jauh dan bisa juga dioperasikan meskipun ada penghalang antara alat dengan pengguna. Salah satu piranti elekronika yang terdapat bluetooth di dalamnya adalah pada smatphone android, di sini bluetooth yang tedapat pada android bisa digunakan untuk kontroling besaran arus, tegangan dan daya listrik.

\section{METODE PENELITIAN}

Alat dan bahan penelitian mencakup berbagai instrumentasi, komponen, serta bahan-bahan yang digunakan dalam proses penelitian, diantaranya :

a. Instrumentasi dan Komponen, yang terdiri dari :

1) Sensor arus ACS712 5A

2) Sensor tegangan ZMPT101B

3) Mikrokontroler Arduino nano

4) Modul Bluetooth HC-05

5) Relay 4 chanel

6) $\operatorname{LCD} 16 \times 2$ 
7) Tang ampere

8) Multimeter digital

9) Papan PCB

b. Alat kerja, yang terdiri dari :
1) Solder
2) timah
3) Obeng plus dan minus
4) Taspen
5) Geraji

\section{c. Jenis Penelitian}

Penelitian yang digunakan dalam proyek ini adalah jenis pengembangan yang fokus pada rancang bangun, Tujuan penelitian pengembangan ini yaitu untuk meningkatkan sistem pengontrolan dan intrumentasi kelistrikan jarak jauh mengunakan teknologi bluetooth dan smartphone. Implementasi pengontrolan dan monitoring menggunakan Bluetooth ini menggunakan komunikasi data dua arah atau dengan kata lain pada sisi hardware dan smartphone dapat sebagai pemancar (tranmistter) dan penerima (receiver).

\section{d. Tahapan Peneltian}

Tahapan penelitian dalam penelitian ini adalah sebagai berikut:

1) Mengkaji beberapa literatur untuk mengkaji teori yang terkait dengan pengukuran besaran listrik, dan sistem komunikasi Bluetooth dengan smartphone

2) Memetakan fungsi kerja keseluruhan komponen yang digunakan untuk rancang bangun.

3) Pemrograman IC mikrokontrol dengan menggunakan software arduino genuino dan setting konfigurasi android dengan alamat dan intruksi khusus dengan aplikasi virtuino. 
4) Mensimulasikan hasil program dengan software proteus 8 untuk menguji keberhasilan dari pemrograman selain itu untuk meminimalisir risiko kerusakan hardware pada rangakian sebenarnya (hardware).

5) pengujian sensor arus ACS712 5A, dan sensor tegangan ZMPT101B untuk mengetahui nilai besaran tegangan yang dikonversikan dari jaringan yang diukur, terhadap tegangann output yang menuju PIN analog mikrokontrol.

6) Merangkai hardware berdasarkan desain yang ada di Proteus 8, selanjutnya program arduino di upload ke dalam IC mikrokontrol menggunakan USB.

7) Melakukan pengujian sistem seperti: pengontrolan peralatan elektronik, pengukuran arus, tegangan, dan daya, kemudian membandingakan pembacaan alat dengan alat ukur yang standar untuk mengetahui nilai galat (error).

8) Dilanjutkan dengan pembahasan kemudian menarik kesimpulan dari hasil percobaan.

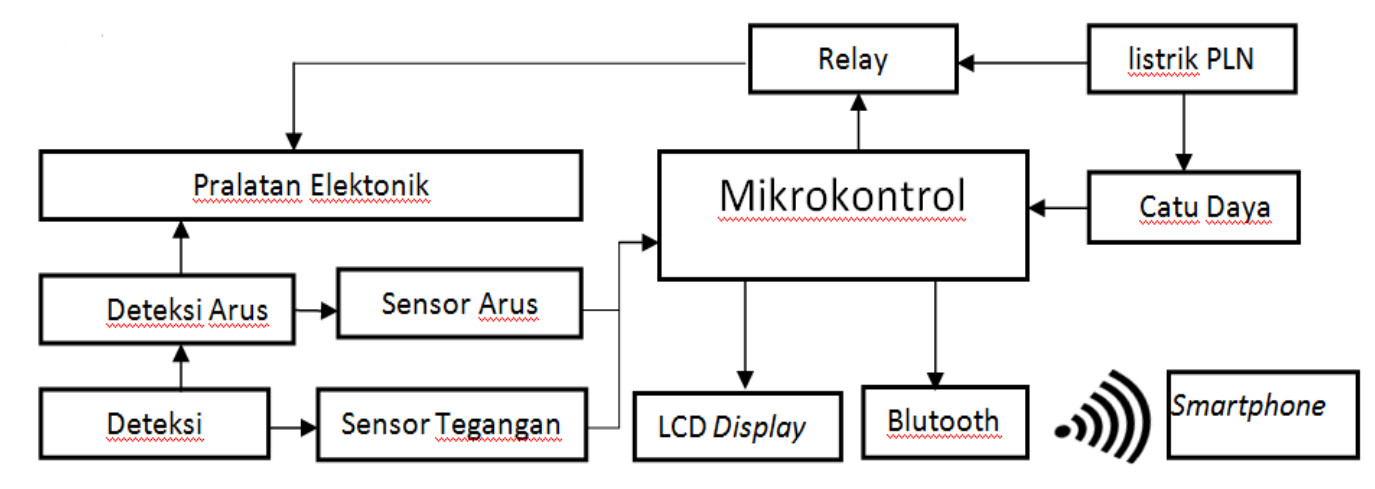

Gambar 1. Diagram Blok Sistem 


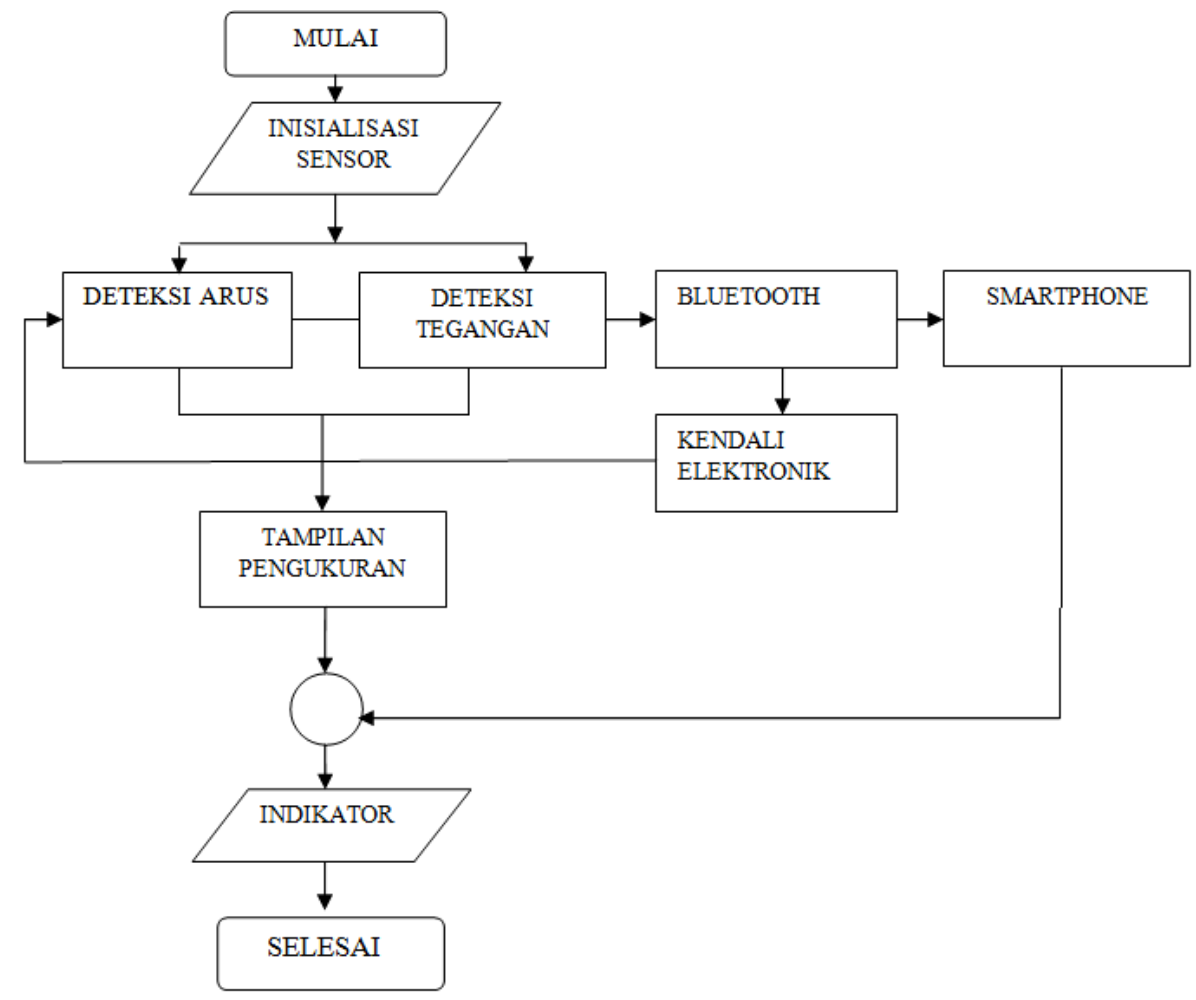

Gambar 2 Alur Penelitian

Teknik penggumpulan data yang digunakan pada penelitian ini dilakukan dengan cara mencatat hasil pengukuran alat yang dirancang dengan alat ukur standar, meliputi besaran tegangan, arus listrik, dan daya semu.

\section{HASIL DAN PEMBAHASAN}

Dari penelitian dihasilkan alat seperti gambar di bawah ini:

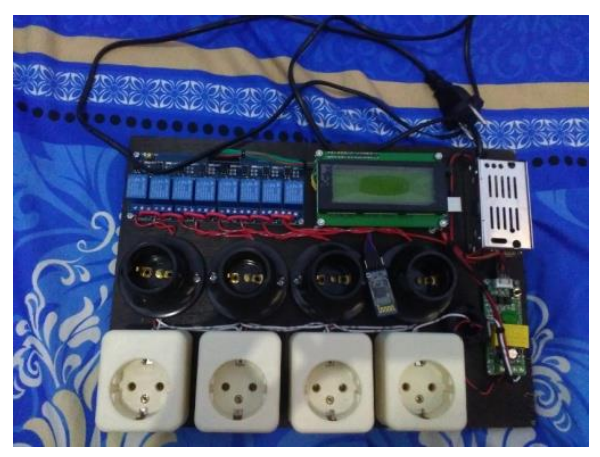

Gambar 3 Alat hasil Penetian 


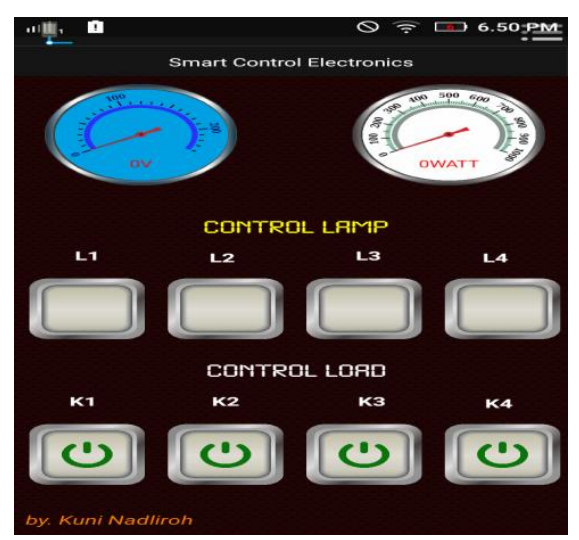

Gambar 4 Display Aplikasi pada Layar Hp

Dari alat penelitian yang telah dirangkai, maka dilakukan pengendalian daya semu pada beberapa piranti elektronik, berikut merupakan hasil dari pengendalian dan pengukuran daya semu melalui peralatan dari hasl penelitian yang mana hasil pengukurannya dibandingkan dengan alat ukur lain yaitu digital power metter untuk mengetahui pakah peralatan tersebut mempunyai daya ukur yang sama atau hampir sama dengan peralatan yang lainnya:

Tabel 1 Data Hasil Pengukuran

\begin{tabular}{cccc}
\hline No & Sampel & $\begin{array}{c}\text { Alat Penelitian } \\
(\text { VA) }\end{array}$ & $\begin{array}{c}\text { watt meter digital } \\
\text { (VA) }\end{array}$ \\
\hline 1 & Kipas Angin & 43 & 43 \\
2 & TV & 12 & 10 \\
3 & Setrika & 348 & 346 \\
4 & Kulkas & 171 & 170 \\
5 & Pompa Air & 241 & 244 \\
\hline
\end{tabular}

Dari data yang terdapat pada tabel di atas bisa dilihat bahwa terdapat perbedaan hasil pengukuran daya semu pada kedua alat tersebut, akan tetapi perbedaan itu tidak mempunyai rentang yang jauh. Daya semu merupakan hasil perkalian antara besar arus yang terdapat dalam suatu piranti elektronika dengan besarnya tegangan yang melewatinya[1]. dalam alat ini akan dibuat alat pengontrol daya semu yang mana akan dihasilkan oleh suatu alat elektronika sebagai luaran yang bisa terukur melalui android yang tehubungan dengan piranti kontroler melalui bluetooth, dimana bluetooth merupakan personal area network tanpa menggunakan kabel. 
pengontrolan daya sangat penting dilakukan sehingga peralatan elektronika bisa bekerja sesuai dengan apa yang operator butuhkan. peralatan ini sangat sederhana sehingga bisa digunakan dalam kehidupana sehari- hari baik dalam skala perusahaan besar maupun dalam skala kecil yaitu rumah tangga[2].

Alat ini menggunakan sistem bluetooth yang terdapat dalam handphone yang mana penggunaan ini dimaksudkan bisa dilakukan oleh semua orang dengan sederhana[3]. penggunaan bluetooth yang digunakan adalah bluetooth HC 05 yang mudah diaplikasikan dan mudah ditemui dipasaran. peralatan ini menggunakan sistem pemrograman IC mikrokontrol software arduino genuino dan setting konfigurasi android dengan alamat dan intruksi khusus dengan aplikasi virtuino, dengan demikian peralatan ini mudah digunakan dan fleksibel[4].

Kontroler arus dalam hal ini digunakan sensor arus ACS712, pemilihan sensor arus ACS 712 ini karena sensor ini mempunyai Hall effect sensor akan menghasilkan sebuah tegangan yang proporsional dengan kekuatan medan magnet yang diterima oleh sensor tersebut. Pendeteksian perubahan kekuatan medan magnet cukup mudah dan tidak memerlukan apapun selain sebuah inductor yang berfungsi sebagai sensornya, sedangkan untuk sensor tegangan menggunakan sensor tegangan ZMPT101B yang mana sensor tegangan ini berfungsi sebagai penurun tegangan serta mengubah tegangan AC menjadi DC melalui jembatan diode, selanjutnya difilter dengan kapasitor dengan menurunkan tegangan selanjutnya dapat digunakan sebagai masukan pada mikrokontroler. penggunaan relay digunakan sebagai pemutus dan penghubung arus yang digunakan untuk menghidupkan alat[5].

Setelah alat siap digunakan maka terlebih dahulu dilakukan uji keberhasilan dengan menggunakan software proteus 8 untuk meminimalisir kerusakan hardware. Langkah yang perlu kita lakukan untuk mendapatkan data besarnya arus dan tegangan adalah sebagai berikut:

a. Nyalakan alat

b. Pastikan android terhubungan dengan alat, dimana penghungannya ini dengan menggunakan pasword sehingga tidak semua android bisa mengendalikan alat ini, sehingga mampu meminimalisir keslahan dalam pengontrolan. 
c. Setelah alat dan android terhubung maka piranti elektronik yang ingin dikendalikan daya semunya dihubungan melalui stop kontak.

setelah dilakukan pengambilan data maka akan didapat data sesuai dengan data yang tertera pada tabel $1 \mathrm{di}$ atas.

\section{KESIMPULAN}

Tujuan dari penelitian ini adalah membuat suatu alat yang dapat digunakan sebagai kontrol daya semu untuk piranti elektronika dan pada penelitian ini telah dibuat alat kontrol daya semu dan telah dibandingkan hasil pengukurannya dengan multimeter dan mempunyai hasil yang tidak jauh berbeda, sehingga bisa dikatakan bahwa alat yang dihasilkan pada penelitian ini mempunyai kelayakan.

\section{DAFTAR PUSTAKA}

[1] Hadi, A. Sistem Distribusi Daya Listrik. Jakarta, Erlangga,1994

[2] Afrizal Fitriandi, E. K. Rancang Bangun Alat Monitoring Arus dan Tegangan Berbasis Mikrokokntroller dengan SMS Gateway, Eletrician Jurnal Rekayasa dan Teknologi Elektro ,10 (2) 87-98, May.2016.

[3] Pauline Rahmiati, G. F. Implementasi Sistem Bluetooth Menggunakan Android dan Arduino untuk Kendali Peralatan Elektronik. Jurnal Elkomika, 2(1) 1-14.Juny.2014

[4] Reynold Rumimper, S. R, Rancang Bangun Alat Pengontrol Lampu Dengan Bluetooth Berbasis Android, E-Journal elektronik dan Komputer , 24-33, 5(3), August. 2016

[5] Aripriharta, S. M., Smart Relay dan Aplikasinya, Yogyakarta, Graha Ilmu, 2004 